\title{
THE RISK FACTORS OF DEATH DUE TO CORONA VIRUS DISEASE 19 IN KENDARI CITY
}

\author{
$\operatorname{Karmila}^{1}$, Timbul Supodo ${ }^{2}, \operatorname{Sunarsih}^{3}$ \\ ${ }^{1,2,3}$ Master of Public Health Study Program, Universitas Mandala Waluya, \\ Kendari, Southeast Sulawesi, Indonesia
}

Corresponding Author : Karmila

Jl. Jend. A. Nasution No. G-37 Tel. 3193176 (0401), Kendari, Indonesia

E-mail: karmila.hely@gmail.com

\begin{abstract}
Background : Corona virus Disease 2019 or Covid-19 is an infectious disease caused by Severe Acute Respiratory Syndrome Corona virus 2 (SARS-Cov-2). Data from the Kendari City Health Office from January to December 2020, the number of confirmed cases of Covid-19 was 3,874 cases with 56 deaths spread throughout Kendari City. The high death rate from corona virus disease19 is caused by several factors. The research objective was to determine the risk factors for death due to corona virus disease 19 (covid-19) in Kendari City.

Methods: This type of research is a case control study conducted from March to April 2021, the number of sample are 49 cases taken by random sampling and 49 controls.

Results: Based on the Odds Ratio (OR) value of pneumonia disease is $8,624>1$, OR of Diabetes Mellitus is 7,994>1, and the respondent's OR of hypertension is 8,653>1.

Conclusion: Pneumonia, diabetes mellitus, and hypertension are the risk factors of death from Covid-19 in Kendari City in 2020. A person suffering from hypertension has the greatest risk of death. Furthermore, the second greatest risk for death is in someone who has pneumonia.
\end{abstract}

Keywords: COVID-19, Pneumonia, Diabetes Mellitus, Hypertension. 


\section{INTRODUCTION}

The coronavirus disease 2019 (Covid-19) is a huge health concern today (1). Coronavirus disease 2019 or Covid-19 is an infectious disease caused by Severe Acute Respiratory Syndrome Coronavirus 2 (SARS-Cov-2). SARS-CoV-2 is a new type of coronavirus that has never been previously identified in humans (2). World Health Organization (WHO) reported that the number of positive cases worldwide during 2020 reached 109 million confirmed cases, 61.6 million recovered cases and 2.42 million deaths occurred worldwide (CFR $4.9 \%$ ) (3). The countries that reported the most confirmed cases and deaths were the United States, Brazil, United Kingdom and Russia (4).

In Indonesia, the number of confirmed cases is increasing every day, there are cases that die, cases are declared positive and cases are cured. The number of positive confirmed cases of COVID-19 during 2020 was 1.23 million cases, 1.04 million recovered cases and 33,596 deaths (5). Southeast Sulawesi Province during 2020 it was reported that the number of positive confirmed cases of Covid-19 was 7,895 cases, the number of recovered cases was 6,990 with a total of 145 deaths spread across 17 districts and cities, with the highest death case in Kendari City with a total of 56 death cases (6).

According to data from the Kendari City Health Office, from January to December 2020, the number of confirmed cases of COVID-19 was 3,874 cases with 56 deaths spread throughout Kendari City (6). The high death rate from coronavirus disease- 19 is caused by several factors such as individual factors. Individual factors include age, biologically the elderly population will experience the aging process which is characterized by decreased body resistance, congenital or comorbid diseases (7). This can make the body more susceptible to disease.
Based on the results of a survey that has been conducted on several positive cases who have recovered and the families of patients who have died due to COVID-19, there are cases of death at the age of 31 years - 45 years, 46 years - 69 years and 70 years and over. As well as more cases of death in men than in women, while in cases of death more in the productive age and the elderly than in adolescence. Based on this background, so the researcher intends to conduct a study with the title "Risk Factors for Death Due to Coronavirus Disease 19 (Covid-19) in Kendari City".

\section{METHODS}

The research method used is a quantitative method with a case control study design (8). To determine the risk factors between the independent variables and the dependent variable retrospectively at the Kendari City (9). The case population in this study was all confirmed positive COVID-19 patients who died and resided in the Kendari City area from 2020 to February 2021, namely 56 people. The control population is all confirmed positive COVID-19 patients who have been declared cured and domiciled in the Kendari City area from 2020 to February 2021, which is 3,824 people. A total sample of 49 cases and 49 controls (10). The variables in this study are death due to Covid-19, pneumonia, diabetes mellitus, and hypertension. Data analysis was carried out in several stages, namely descriptive, inferential analysis (11) and epidemiological analysis (Odd Ratio), and logistic regression (12). This analysis was carried out using the help of statistical applications.

\section{RESULTS}

Table 1 shows that out of 51 respondents, there were 18 respondents (35.3\%) who did not have pneumonia but died from Covid-19 while there were 33 respondents (64.7\%) who did not have 
Karmila, Supodo, T., Sunarsih.

DOI: 10.36566/ijhsrd/Vol3.Iss2/93

https://ijhsrd.com/index.php/ijhsrd

e- ISSN: 2715-4718

pneumonia but were healthy from Covid-19. Meanwhile, of the 47 respondents, 31 respondents $(66 \%)$ who experienced pneumonia eventually died while there were 16 respondents (34\%) who had pneumonia but recovered from the confirmation of Covid-19. The statistical test results show that $\mathrm{p}$ value $=0.002<0.05$. Also obtained the $\mathrm{OR}=8,624(2,460-30,232)$. Logistic regression test results is 0.001 .

Table 2 shows that of 75 respondents, there are 31 respondents $(41.3 \%)$ who did not have Diabetes Mellitus but died from Covid-19, while there were 44 respondents (58.7\%) who did not have Diabetes Mellitus but recovered from Covid-19 confirmation. Meanwhile, out of 23 respondents, there were 18 respondents $(78.3 \%)$ who died due to risk factors for Diabetes Mellitus and 5 respondents $(21.7 \%)$ who had Diabetes Mellitus recovered from Covid-19 confirmation. The results of statistical tests show that $\mathrm{p}$ value $=0.002<0.05$. Also obtained the OR $=7,994(1,803-35,442)$. Logistic regression test results is 0.006 .

Table 3 shows that out of 59 respondents, there were 21 respondents (35.6\%) who did not have hypertension but died from Covid-19 while there were 38 respondents (64.4\%) who did not have hypertension but recovered from Covid-19. Meanwhile, out of 39 respondents, 28 respondents $(71.8 \%)$ who experienced hypertension died from Covid-19, and 11 respondents $(28.2 \%)$ who experienced hypertension recovered from the effects of Covid-19. The statistical test results show that $\mathrm{p}$ value $=0.000<0.05$. Also obtained the $\mathrm{OR}=8,653 \quad(2,306-32,477)$. Logistic regression test results is 0.001 .

Table 1

The Effect of Respondents' Pneumonia on Deaths Due to Covid-19

\begin{tabular}{|c|c|c|c|c|c|c|c|}
\hline \multirow{3}{*}{ Pneumonia } & \multicolumn{4}{|c|}{ Patient Final Status } & \multirow{2}{*}{\multicolumn{2}{|c|}{ Total }} & \multirow[b]{2}{*}{ Statistics test } \\
\hline & \multicolumn{2}{|c|}{$\begin{array}{c}\text { Heal } \\
\text { (Control) }\end{array}$} & \multicolumn{2}{|c|}{$\begin{array}{l}\text { Died } \\
\text { (Case) }\end{array}$} & & & \\
\hline & $\mathrm{n}$ & $\%$ & $\mathrm{n}$ & $\%$ & $\mathrm{n}$ & $\%$ & $\mathrm{P}$ value $=0.002$ \\
\hline No Pneumonia & 33 & 64.7 & 18 & 35.3 & 51 & 100 & $\mathrm{OR}=8,624$ \\
\hline Pneumonia & 16 & 34 & 31 & 66 & 47 & 100 & $\mathrm{LL}=2.460$ \\
\hline Total & 49 & 50.0 & 49 & 50.0 & 98 & 100 & $\mathrm{UL}=30,232$ \\
\hline
\end{tabular}

Table 2

The Effect of Respondents' Diabetes mellitus on Deaths Due to Covid-19

\begin{tabular}{|c|c|c|c|c|c|c|c|}
\hline \multirow{3}{*}{$\begin{array}{l}\text { Diabetes } \\
\text { mellitus }\end{array}$} & \multicolumn{4}{|c|}{ Patient Final Status } & \multirow{2}{*}{\multicolumn{2}{|c|}{ Total }} & \multirow[b]{2}{*}{ Statistics test } \\
\hline & \multicolumn{2}{|c|}{$\begin{array}{c}\text { Heal } \\
\text { (Control) }\end{array}$} & \multicolumn{2}{|c|}{$\begin{array}{l}\text { Died } \\
\text { (Case) }\end{array}$} & & & \\
\hline & $\mathrm{n}$ & $\%$ & $\mathrm{n}$ & $\%$ & $\mathrm{n}$ & $\%$ & $\mathrm{P}$ value $=0.002$ \\
\hline $\begin{array}{l}\text { No Diabetes } \\
\text { Mellitus }\end{array}$ & 44 & 58.7 & 31 & 41.3 & 75 & 100 & $\begin{array}{l}\mathrm{OR}=7,994 \\
\mathrm{LL}=1,803\end{array}$ \\
\hline $\begin{array}{l}\text { Diabetes } \\
\text { mellitus }\end{array}$ & 5 & 21.7 & 18 & 78.3 & 23 & 100 & $\mathrm{UL}=35,442$ \\
\hline Total & 49 & 50.0 & 49 & 50.0 & 98 & 100 & \\
\hline
\end{tabular}


Karmila, Supodo, T., Sunarsih.

DOI: $10.36566 / 1 j h s r d / V o l 3 . I s s 2 / 93$

https://ijhsrd.com/index.php/ijhsrd

Table 3

The Effect of Respondents' Hypertension on Deaths Due to Covid-19

\begin{tabular}{|c|c|c|c|c|c|c|c|}
\hline \multirow{3}{*}{ Hypertension } & \multicolumn{4}{|c|}{ Patient Final Status } & \multirow{2}{*}{\multicolumn{2}{|c|}{ Total }} & \multirow[b]{2}{*}{ Statistics test } \\
\hline & \multicolumn{2}{|c|}{$\begin{array}{c}\text { Heal } \\
\text { (Control) }\end{array}$} & \multicolumn{2}{|c|}{$\begin{array}{l}\text { Died } \\
(\text { Case })\end{array}$} & & & \\
\hline & $\mathrm{n}$ & $\%$ & $\mathrm{n}$ & $\%$ & $\mathrm{n}$ & $\%$ & \\
\hline No Hypertension & 38 & 64.4 & 21 & 35.6 & 59 & 100 & $P$ value $=0.000$ \\
\hline Hypertension & 11 & 28.2 & 28 & 71.8 & 39 & 100 & $\mathrm{OR}=8,653$ \\
\hline Total & 49 & 50.0 & 49 & 50.0 & 98 & 100 & $\begin{array}{c}\mathrm{LL}=2,306 \\
\mathrm{UL}=32,477\end{array}$ \\
\hline
\end{tabular}

\section{DISCUSSION}

\section{The Effect of Pneumonia on Deaths Due to Covid-19}

Pneumonia Coronacirus Disease 2019 (Covid-19) is an inflammation of the lung parenchyma caused by severe acute respiratory syndrome coronavirus 2 (SARSCoV-2) (13). The syndrome of clinical symptoms that appear varies from uncomplicated (mild) to septic shock (severe) (14).

The results of the Bivariable analysis showed that of the 98 respondents consisting of case and control samples, that the number of cases that died due to pneumonia exposed to COVID-19 was 31 people $(66 \%) \%)$ this was due to a history of pneumonia suffered by the patient and the number of cases diagnosed 18 people (35.5\%) died from COVID-19 but did not have pneumonia, this was due to no history of pneumonia suffered by the patient. Meanwhile, 16 recovered patients who were exposed to COVID-19 suffered from pneumonia (34\%) and 33 recovered patients who did not have pneumonia but were exposed to COVID-19 $(64.7 \%)$.

The results of the multivariable analysis show that pneumonia has an effect on deaths due to covid-19. Patients with COVID-19 with pneumonia have a risk of 8,624 times $(95 \%$ CI $2,460-30,232)$ to die from COVID-19 compared without pneumonia but exposed to COVID-19.

\section{The Effect of Diabetes Mellitus on Deaths Due to Covid-19}

The results of this study indicate that there is an influence between comorbid Diabetes Mellitus and death due to Covid-19. The subjects in this study showed that Covid-19 patients with Diabetes Mellitus had a risk of $7,994(95 \%$ CI $1,80335,442)$ to experience death from Covid-19 compared to those without Diabetes Mellitus. Various studies have linked the relationship between Covid-19 and Diabetes Mellitus. Several studies and cases have reported poorer Covid-19 prognosis and higher mortality rates in diabetes mellitus patients. Severe symptoms in Covid-19 patients often occur in those who are accompanied by comorbidities, one of which is Diabetes Mellitus. A study in the UK states that the risk of death increases by 2-3 times in 23.000 cases to Covid-19 patient with DM (15).

Covid-19 patients with comorbid diabetes mellitus are 2.17 times more likely to die than patients without comorbid diabetes mellitus (16). The relationship between DM and Covid-19 is based on various pathophysiologies, namely immune mechanisms and angiotensin-converting enzyme 2 (ACE2). DM patients generally have a compromised immune response and longer viral clearance or viral clearance, 
making them more susceptible to infection. The condition of diabetes mellitus itself is associated with reduced ACE2 which is commonly expressed in various organs of the body, such as the lungs, kidneys, gastrointestinal tract, and vascular endothelium. ACE2 receptors in the lung have an important role in the regulation of anti-inflammatory and antioxidant, so that the decrease in ACE2 expression can increase inflammation, pulmonary edema, the risk of severe lung damage (17).

The increasing severity in Covid-19 patients with Diabetes Mellitus has led the Indonesian Ministry of Health (2020) to release preventive measures for people with Diabetes Mellitus during the Covid-19 pandemic, some of which are maintaining body condition and eating patterns, besides that it is also necessary routinely. to check blood sugar at home. Otherwise, watch for signs of elevated blood sugar (such as frequent urination, feeling very thirsty, headaches, tiredness, and lethargy). If you are sick or your blood sugar rises, you should immediately consult a doctor (18).

\section{The Effect of Hypertension on Deaths Due to Covid-19}

The results of the multivariable analysis showed that hypertension had an effect on deaths from Covid-19. Several organizations have emphasized the fact that controlling blood pressure can reduce the severity of the disease burden, although it has no effect on susceptibility to SARSCoV-2 virus infection. Nevertheless, the fact is that hypertension and other forms of cardiovascular disease are also frequently found in Covid-19 patients. Patients in this condition are often treated with angiotensinconverting enzyme (ACE) inhibitors and angiotensin receptor blockers (ARBs). The virus that causes Covid-19 binds to ACE2 in the lungs to enter cells. ACE inhibitors and ARBs have been shown to increase ACE2, which could theoretically increase the binding of SARS-Cov-2 to the lungs and its pathophysiological effects that could lead to greater lung injury (19).

As previously demonstrated, hypertension is the most common underlying disorder among COVID-19 patients. High prevalence of hypertension (59.8-63.5\%), among COVID-19 patients may be accompanied by death. A study conducted by Lippi et al (2020), reported that hypertension had a higher risk of increasing the severity of Covid-19 (20). Hypertension is the most common comorbidity among Covid-19 patients and it has been frequently reported that hypertension can increase the severity of Covid-19 infection. Thus, many people with hypertension are worried that they will end up with severe Covid-19 infection and poor clinical outcomes (21).

The results of the multivariable analysis of the study showed that hypertension had a risk of 8,653 times (CI: $95 \% 2,306-32,477)$ to experience death from COVID-19 compared to those who were not hypertensive but exposed to COVID-19.

\section{CONCLUSION}

In this study pneumonia, diabetes mellitus, and hypertension are risk factors for death from Covid-19 in Kendari City in 2020. A person suffering from hypertension has the greatest risk of death. Furthermore, the second greatest risk for death is in someone who has pneumonia.

\section{REFERENCES}

1. Salyer SJ, Maeda J, Sembuche S, Kebede Y, Tshangela A, Moussif M, et al. The first and second waves of the COVID-19 pandemic in Africa: a crosssectional study. The Lancet. 2021;397(10281):1265-75.

2. Daniel J. Education and the COVID-19 pandemic. Prospects. 2020;49(1):91-6. 
Karmila, Supodo, T., Sunarsih.

DOI: 10.36566/ijhsrd/Vol3.Iss2/93

https://ijhsrd.com/index.php/ijhsrd

3. Cucinotta D, Vanelli M. WHO declares COVID-19 a pandemic. Acta Bio Medica: Atenei Parmensis. 2020;91(1):157.

4. Omer SB, Malani P, Del Rio C. The COVID-19 pandemic in the US: a clinical update. Jama. 2020;323(18):1767-8.

5. Indonesian Ministry of Health. Latest Development Situation (COVID-19). Jakarta: Ministry of Health of the Republic of Indonesia; 2020.

6. Covid-19 task force. Covid-19 Case Report. In: Health D, editor. Kendari: Health Office of Southeast Sulawesi Province; 2020.

7. Jayadipraja EA, Daud A, Assegaf AH. Air Pollution and Lung Capacity of People Living around the Cement Industry. Public Health of Indonesia. 2016;2(2):76-83.

8. Notoatmodjo S. Health Research Methods. Jakarta: Rineka Cipta; 2014.

9. Sugiyono. Quantitative Qualitative Research Methods and R\&D. Bandung: Alfabeta; 2019.

10. Kendari City Health Office. Kendari City Health Office Profile. Kendari: Kendari City Health Office; 2020.

11. Hermawan I. Educational Research Methodology (Qualitative, Quantitative and Mixed Method): Hidayatul Quran; 2019.

12. Arikunto S. Research Procedure A Practical Approach. Jakarta2019.

13. Calabrò L, Peters S, Soria J-C, Di Giacomo AM, Barlesi F, Covre A, et al. Challenges in lung cancer therapy during the COVID-19 pandemic. The Lancet Respiratory Medicine. 2020;8(6):542-4.

14. Solomon MD, McNulty EJ, Rana JS, Leong TK, Lee C, Sung S-H, et al. The Covid-19 pandemic and the incidence of acute myocardial infarction. New England Journal of Medicine. 2020;383(7):691-3.

15. Lestari N, Ichsan B. Diabetes Mellitus as a Risk Factor for Severity and Death of
Covid-19 Patients: Meta-Analysis. Biomedical. 2021;13(1):83-94.

16. Kun'ain UIA, Rahardjo SS, Tamtomo DG. Meta-analysis: the effect of diabetes mellitus comorbidity on the risk of death in COVID-19 patients. Indonesian Journal of Medicine. 2020;5(4):368-77.

17. Utami UR. Literature Study: Self Management in Type 2 Diabetes Mellitus Patients with a Family Centered Care Approach in the Srondol Public Health Center Semarang. 2020.

18. Muniyappa R, Gubbi S. COVID-19 pandemic, coronaviruses, and diabetes mellitus. American Journal of Physiology-Endocrinology and Metabolism. 2020;318(5):E736-E41.

19. Schiffrin EL, Flack JM, Ito S, Muntner P, Webb RC. Hypertension and COVID19. Oxford University Press US; 2020.

20. Lippi G, Lavie CJ, Sanchis-Gomar F. Cardiac troponin I in patients with coronavirus disease 2019 (COVID-19): evidence from a meta-analysis. Progress in cardiovascular diseases. 2020.

21. Hosseinzadeh A, Moeinaddini A, Ghasemzadeh A. Investigating factors affecting severity of large truck-involved crashes: Comparison of the SVM and random parameter logit model. Journal of safety research. 2021. 